\title{
DETERMINATION OF INDIVIDUAL TAXPAYER COMPLIANCE IN INDONESIA: A CASE STUDY
}

\author{
Sri Dewi Anggadini \\ Faculty Economic and Business, Universitas Komputer Indonesia, Bandung, Indonesia \\ Surtikanti Surtikanti \\ Faculty Economic and Business, Universitas Komputer Indonesia, Bandung, Indonesia
}

Ari Bramasto

Faculty Economic and Business, Universitas Langlang Buana, Bandung, Indonesia

Egi Fahrana

Universitas Komputer Indonesia, Bandung, Indonesia

\begin{abstract}
A citizen is required to comply with this obligation to pay taxes following the provisions of a country's applicable legislation. This study aims to test the impact of tax knowledge, modernize tax administration and taxpayer awareness, and determine which factors have the most significant impact on taxpayer compliance. The study's research method is descriptive and confirmatory analysis with a quantitative approach, with many samples consisting of 100 respondents. The results show that taxpayer compliance in tax settlement is inextricably linked to factors such as Tax Knowledge, Modernization of the Tax Administration System, and Taxpayer Awareness. It is possible to conclude that Tax Knowledge has a significant positive impact on Taxpayer Compliance. The modernization of the tax administration system has a significant positive effect on taxpayer compliance. Taxpayer Awareness has a significant positive impact on tax compliance in Indonesia. It is possible to explain how independent variables influence taxpayer compliance. This research is essential to encourage taxpayers to comply with their obligations by using a behavioral approach and current tax policies, which will increase economic prosperity in Indonesia.
\end{abstract}

Keywords:Tax Knowledge, Modernization of Tax Administration System, Taxpayer Compliance, Taxpayer Awareness

DOI: http://dx.doi.org/10.15549/jeecar.9i1.883

\section{INTRODUCTION}

Taxation is a common phenomenon that is always interesting because tax receipts play a vital role in securing the State Budget each year. In the economic field, taxes are the most significant funds received by a state and are intended to be used for the welfare of its citizens. The sociological aspect of taxation is examined in society, focusing on the consequences or impacts of levies on a 
community and what results can be communicated to the community. The tax collection process in Indonesia is still difficult to manage and has fallen short of government expectations (Kustiawan et al., 2019). The tax collection process is not easy because it involves handing over some people's income to the state and encountering difficulties in the voting process (Masari \& Suartana, 2019).

When taxpayers fulfill their obligation to pay state taxes, they are said to be compliant (Kustiawan et al., 2019). To meet the government's target, the Directorate General of Taxes (DGT) had several options for increasing state revenues in the tax sector, including making changes by creating a program that makes it easier for people to pay their taxes (taxpayers). The program is an online e-filing system that assists taxpayers incorrectly preparing, processing, and reporting taxes to the tax office on time. However, the e-filing system has resulted in significant changes in taxpayer compliance. This system is not simple to put in place. It is because taxpayers continue to refuse to use an e-filing system, although the e-filing system has provided numerous benefits (Pratama, 2017; Li, W, 2017; Purnamasari \& DPS, 2018; Mohammed \& Sanusi, 2020).

According to Osipov (2017), obedient taxpayers in fulfilling their tax obligations are significant because they are responsible for accurately and timely determining their (taxpayers') amount of tax owed, reporting, and paying. If taxpayer compliance is high, state tax revenues rise as well. As a result, it must be scrutinized more closely in matters affecting taxpayer compliance. According to Olaoye and Kehinde (2017), taxpayer compliance has an impact on taxpayer awareness, tax sanctions, and physical services. Meanwhile, modernization of the tax administration system, according to Pratama (2017), is another factor that can affect taxpayer compliance. According to Solehzoda (2017), one method the government uses to improve taxpayer compliance is to modernize the tax administration system. It becomes critical because increasing taxpayer compliance increases the state's tax revenues. In addition to modernizing the tax administration system, Li, W. (2017) stated that tax revenue receipts could be maximized if taxpayer awareness in complying with applicable tax obligations is high. Taxpayer awareness is the factor that has had the greatest impact on taxpayer compliance (Azemi et al., 2020; Anggadini, 2015; Ouachene \& Belazouz, 2017).

This research is a development of study conducted by Olaoye \& Kehinde (2017) and Li (2017) with descriptive quantitative research with survey research methods. The conclusion drawn from the test results is that the modern tax administration system has no significant impact on taxpayer compliance. It indicates that the research results do not correspond to the intended objectives, namely an increase in the number of taxpayers who pay their taxes. However, Bernard et al. (2018) demonstrate that modern tax administration can significantly impact taxpayer compliance. Pratama (2017) conducted the following study using descriptive quantitative research. According to the results of the tests, tax knowledge has a significant impact on taxpayer compliance, whereas taxpayer awareness has no considerable effect on taxpayer compliance. However, research conducted by Azemi et al. (2020) with quality-of-service tax authority partially on tax knowledge has no positive impact, and research conducted by Li, W. (2017) that tax awareness is not significant at a level of tax compliance.

Therefore, we are interested in researching the same title on different objects. The difference between this research and previous research lies in dimensions used to measure tax knowledge variables, modernization of tax administration system, taxpayer awareness, and taxpayer compliance. It is necessary to have a more profound examination to resolve all problems quickly with these conditions. Efforts made are to conduct research related to elements that affect taxpayers to carry out their obligations in tax settlement, especially regarding tax knowledge, modernization of the administrative system, and taxpayer awareness in Indonesia. The study was conducted to provide an overview that some taxpayers still do not care about their obligations in tax settlement to hamper economic growth (Veit, A, 2019). The size of the area, the large population, and the dynamics of economic activity are challenges in enforcing taxation in Indonesia. The ratio mismatch between tens of thousands of tax officials and millions of taxpayers has resulted in the less-than-optimal implementation of taxation in Indonesia. To address this, it may be 
necessary to modernize tax administration that is simple, fast, and easy to do so that taxes can optimally reach millions of people and thousands of organizations through information and communication technology (Angagdini, 2017). The novelty of this research is in the form of an easy explanation in complying with tax obligations. One of the causes of the lack of taxpayer compliance is the administrative process that is difficult, ineffective, and inefficient, resulting in high compliance costs.

\section{LITERATURE REVIEW}

All information about taxes is essential for the public to know to increase knowledge and complete tax documents independently. A taxpayer tends to carry out obligations tax if they already know tax regulations, compared to taxpayers who do not understand. Higher knowledge of taxpayers on tax regulations may be less likely a taxpayer is to violate rules. Taxpayers who do not care about their tax obligations and awareness to pay taxes still less influence how taxation in Indonesia. Meanwhile, taxpayer compliance is identified by a condition in which the taxpayer fulfills all tax obligations and to carries out taxation (An and Wilson, 2016).

\section{H1: Tax knowledge affects taxpayer compliance}

A taxpayer becomes obedient in performing his obligations, highly expected by the government. Still, to obedient, many factors are supporting it, one of which is the tax system implements, services provided to taxpayers, enforcement of tax laws, tax checks, and applicable tax rates. Besides, a simple tax system is also important because a more complex tax system will affect taxpayer compliance. Modernization tax administration system as a reform in providing ease of service and gives effect to taxpayer compliance in carrying out its tax obligations. It is because taxpayers report their taxes by visiting the nearest tax offices. If an existing system has satisfied taxpayers, taxpayers themselves will pay more attention to their obligations as citizens settle their taxes.

H2: Modernization in the tax administration system affects taxpayer compliance

Tax awareness will arise if the taxpayer understands the usefulness of the tax itself. In raising tax awareness, taxpayers need a positive understanding of the implementation of taxes so that tax awareness arises in fulfilling their tax obligations (Bernard et al., 2018). Bernard et al. (2018) proved taxpayer awareness has no significant effect on WPOP compliance, while Bornman \& Ramutumbu (2019) and Cechovsky (2018) proved tax awareness has a substantial and positive impact on taxpayer compliance. Therefore, we made hypotheses, namely:

H3: Taxpayer awareness affects taxpayer compliance.

It can be explained that hypothesis 3 has the same characteristics as hypothesis 1 and hypothesis 2 . The whole hypothesis explains the provisional answer to the reinforcing factors predicted to affect taxpayer compliance.

\section{METHODOLOGY}

This study consists of quantitative research methods based on a philosophy of positivism. It examines both the population and samples to be analyzed. The sampling technique evaluates random data and information collected with research instruments, then analyzes quantitative statistic data to test a predetermined hypothesis. For example, in Pratama Bandung, the 211,474 individual taxpayers registered in Indonesia. Sampling is carried out for time and cost efficiency because not all individual taxpayers can object to this research. A sample is a limited population that should represent the population. Therefore, a selection is a portion of the selected population representing that population. The sampling technique that we used is the Simple Random Sampling technique. The sampling technique in this study applies to a total sample of 100 taxpayers.

Analysis of research data using SPSS Software tools was carried out in several stages: validity, reliability, normality, heteroscedasticity, and multicollinearity test.

Furthermore, the R2 (R Square) test, F Test (Simultaneous), and T-test (Partial) were conducted to answer the research hypothesis by the magnitude of influence in each variable partially and simultaneously. Response of questionnaires rate is acceptable, and answers can be processed. Data analysis multi regressions to 
find an influence of factors affecting taxpayers' compliance in paying their obligations. The steps used in this analysis are as follows:

- Finding the regression equation for the three predictors.

The regression equation is as follows:

$$
\mathrm{Y}=\mathrm{a}+\mathrm{b} 1 \mathrm{X} 1+\mathrm{b} 2 \mathrm{X} 2+\mathrm{b} 3 \mathrm{X} 3
$$

- Finding the coefficient of multiple determination $\left(\mathrm{R}^{2}\right)$ between $\mathrm{X} 1$ and $\mathrm{X} 2$ with

The coefficient of determination can be calculated using the following formula:

$$
\mathrm{R}^{2}=\left(\operatorname{Ry}\left({ }_{1,2,3}\right)\right)^{2}
$$

- Testing the significance of multiple regression with the $F$ test.

Test the significance of multiple correlation coefficients can use the following formula:

$$
\frac{R(N-m-1}{m(1-R 2)}
$$

This was then checked with the F table based on the $5 \%$ significance level. If the calculated $\mathrm{F}$ is smaller than the $\mathrm{F}$ table, there is no significant effect between the independent and dependent variables.

\section{DISCUSSION}

Validity tests are used to determine each indicator in a questionnaire that we obtained that is valid. Questionnaires as research instruments are declared valid to reveal a minimum of results. The method can be declared valid if the calculation result of the correlation coefficient indicates a correlation coefficient of 0.3 or more. Validity data shows accuracy between data on research objects and data collected by researchers-testing using statistical processing tool SPSS 20.0.

Measure three variables have a validity coefficient more significant than a critical value of 0.3 (> 0.30). Therefore, all statements are declared valid. Valid data shows accuracy between data that occurs in research objects and data collected by researchers. Results of reliability testing of research instruments Knowledge taxation (X1), Modernization of tax administration system (X2), and Taxpayer Awareness (X3) to Individual Taxpayer
Compliance $(\mathrm{Y})$ is calculated using Cronbach's Alpha because the scale used in this research instrument is Likert scale. A data is said to be reliable when $>$ is 0.7 . There are three variables consist of variable Knowledge taxation (X1), the variable Modernization in tax administration system (X2), taxpayer awareness (X3), and Individual Taxpayer Compliance (Y) has a value of Cronbach's Alpha > 0.60. It indicates that the instrument of these three variables can be relied on as a tool to measure research variables repeatedly. Results of descriptive analysis prove that the tax knowledge variable has 53\% of respondents' responses. This figure is in $52 \%-68 \%$ interval and is included in the Good enough category. Therefore, it can be concluded that tax knowledge in Indonesia. is classified as good. It means that majority of respondents have good tax knowledge. However, some individual taxpayers still have an inadequate understanding of taxation; this is evident from the gap found of 51\%. Results of descriptive analysis that have been carried out have a percentage value obtained of $63 \%$. This figure is in $52 \%-68 \%$ interval and is included in a pretty good category. Therefore, modernization in the tax administration system in Indonesia can be categorized as good. However, some respondents still think that the tax administration system is not too good, as evidenced by the gap found by $32 \%$.

Results of descriptive analysis that have been carried out have a percentage value obtained of $71 \%$. This figure is in $68 \%-84 \%$ interval and is considered good. Therefore, it can be concluded that Taxpayer Awareness in Indonesia is good. However, some respondents still have poor awareness by a gap found of $29 \%$. Results of descriptive analysis that have been carried out have a percentage value obtained of $66 \%$. This figure is in 52 to $68 \%$ interval and is included in a pretty good category. Therefore, it can be concluded that the compliance of individual taxpayers in Indonesia is good. The majority of taxpayers are obedient in implementing their tax obligations. However, some are still not obedient, evidenced by the existence of a gap found, namely $34 \%$. After describing each variable in this study, statistical testing is carried out to test whether independent variables affect dependent variables. Statistical carried out using multiple regression analysis through the following stages: multiple regression analysis, correlation analysis, determination analysis, and hypothesis testing conducted by SPSS Version 20 software before 
hypothesis, using multiple regression analysis, assumptions must be met analysis conclusions do not become biased, including multicollinearitytests, heteroscedasticity-tests, normality-tests, and linearity-tests.

Multiple linear regression analysis aims to test the influence of Taxation Knowledge (X1), Modernization in Tax Administration System (X2), and Taxpayer Awareness (X3) on Individual Taxpayer Compliance (Y). Results of calculation of linear regression coefficients are multiple by using the help of SPSS software version 20.0 as follows:

Value of Unstandardized Coefficients b is value of constant of regression coefficient, which is value of $\mathrm{a}=-6.491 ; \mathrm{b} 1=0.437$ and $\mathrm{b} 2=0.704$ and b3 $=0.354$, multiple regression equation, follows:

$Y=-6.491+0.437 b 1+0.704 b 2+0.354 b 3$

According to Cechovsky (2018), correlation analysis shows the strength and direction between two or more variables. References are expressed in negative or positive relationships, while weakness or strength of a relationship is described in the magnitude of a correlation coefficient, including:

1) Correlation tax knowledge and individual taxpayer compliance. Based on output results from data processing, the correlation coefficient value for tax knowledge with individual taxpayer compliance is 0.792 , which is included in the interval score between $0.60-0.792$. It shows a strong relationship between tax knowledge and individual taxpayer compliance.

2) Correlation between modernizations in tax administration system with individual taxpayer compliance. Result's data processing obtained value of correlation coefficient for modernization in tax administration system with individual taxpayer compliance of 0.909, which results are included in interval score between 0.80 - 1,000. It shows a strong relationship between modernizations of the tax administration system and individual taxpayer compliance.

3) Correlation between both variables (taxpayer awareness and individual taxpayer compliance). Results of output from data processing and correlation coefficient value for taxpayer awareness and compliance are obtained. Results of the production from data processing, the correlation coefficient for taxpayer awareness and compliance with individual taxpayers is 0.637 , which are included in interval score between 0.60 - 0.799. This shows a strong relationship between taxpayer awareness and individual taxpayer compliance.

Influence of independent variable on the dependent variable in percent, a coefficient determination is used following by formula:

$$
\mathrm{KD}=R^{2} x 100 \%
$$

Partial determination coefficient value of tax knowledge variable with individual taxpayer compliance is as follows $\mathrm{Kd}=(0.792)^{2} \times 100 \%=$ $62.73 \%$. It means the influence of tax knowledge variable on individual taxpayer compliance is $62.73 \%$. The remaining $37.27 \%$ are by other factors which are not analyzed, such as quality of tax authorities, perceptions of the effectiveness of tax system, tax sanctions, social norms, trust in government, and other factors. Partial determination coefficient value of variable modernization of tax administration system with individual taxpayer compliance is as follows $\mathrm{Kd}=$ (0.909) $2 \times 100 \%=82.63 \%$. It means that the influence of the modernization of the tax administration system on individual taxpayers' compliance is $82.63 \%$. The remaining $17.37 \%$ influence is given by other factors not examined in this study. Among them are the quality of tax authorities, perceptions of effectiveness, tax system, tax sanctions, social norms, trust in government, and others. Partial determination coefficient value of taxpayer awareness variable with individual taxpayer compliance is as follows $\mathrm{Kd}=(0.637) 2 \times 100 \%=40.58 \%$. It means that the taxpayer awareness variable's influence on individual taxpayers' compliance is $40.58 \%$. The remaining $59.42 \%$ are influenced by other factors, which are not examined, such as quality of tax authorities, perceptions of the effective taxation system, tax sanctions, social norms, trust in government, and other factors.

A. Tax Knowledge (X1) Against Individual Taxpayer Compliance (Y) (Hypothesis 1)

H01: Tax Knowledge does not affect individual taxpayer compliance

Ha1: Tax Knowledge affects individual taxpayer compliance 
It can be seen that the $\mathrm{T}_{\text {count }}$ value for the tax knowledge variable is 2.311. Values are compared with the $T_{\text {table }}$ value in the $T$ distribution table. With $\alpha=0.05, \mathrm{df}=\mathrm{n}-\mathrm{k}-1=$ $30-3-1=26, T_{\text {table }}$ value is \pm 2.05553 . It is known that $\mathrm{T}_{\text {count }}$ for $\mathrm{X} 1$ is $2.311>\mathrm{T}_{\text {table }}$ value is 2.05553, then $\mathrm{H} 1$ is accepted, and $\mathrm{HO}$ is rejected. This result also shows Significant value obtained is 0.029 . This value is less than 0.05 , which means that this test is significant. It can be said that taxpayers' compliance depends on tax knowledge.

B. Modernization of tax administration system (X2) Against Individual Taxpayer Compliance (Y) (Hypothesis 2)

H02: Modernization of tax administration system does not affect individual taxpayer compliance.

Ha2: Modernization of tax administration system affects individual taxpayer compliance.

It can be seen that $\mathrm{T}_{\text {count }}$ is a value of the tax administration system of modernization variable equal to 2.407. This value is compared with the $T_{\text {table }}$ value in the $T$ distribution table. With $\alpha=0.05, \mathrm{df}=\mathrm{n}-\mathrm{k}-1=$ 30-3-1 $=26, \mathrm{~T}_{\text {table }}$ value is \pm 2.05553 . It is known that the $\mathrm{T}_{\text {count }}$ for $\mathrm{X} 1$ is $2.407>\mathrm{T}_{\text {table }}$ value is 2.05553, then $\mathrm{H} 1$ is accepted and $\mathrm{H} 0$ is rejected. This result also shows Significant value. Obtained is 0.023 . This value is less than 0.05 , which means that this test is significant. It can be said that taxpayers' compliance depends on the modernization of the tax administration system.

C. Taxpayer Awareness (X3) Against Individual Taxpayer Compliance (Y) (Hypothesis 3)

H03: Taxpayer Awareness does not affect individual taxpayer compliance

Ha3: Taxpayer awareness affects individual taxpayer compliance

It can be seen, $\mathrm{T}_{\text {count }}$ value for the taxpayer awareness variable is 2,737 . This value is compared with the $T_{\text {table }}$ value in the $T$ distribution table. With $\alpha=0.05, \mathrm{df}=\mathrm{n}-\mathrm{k}-1=$ $30-3-1=26, T_{\text {table }}$ value is \pm 2.05553 . It is known that the $\mathrm{T}$ count for $\mathrm{X} 1$ is $2.737>\mathrm{T}_{\text {able }}$ value is 2.05553, then $\mathrm{H} 1$ is accepted and $\mathrm{HO}$ is rejected. Shows significant value obtained is 0.011 . This value is less than 0.05 , which means that this test is significant. It can be said that compliance with taxpayers depends on taxpayer awareness.

\section{Influence of Taxation Knowledge on Individual Taxpayers}

Results indicate a positive and significant influence between tax knowledge and individual taxpayer compliance (Evans \& Holland, 2016). Several factors influence the impact of tax knowledge on individual taxpayer compliance. Highest score for the tax knowledge variable is found in the indicator of knowing if state revenue tax is through instruments in item 2, like knowledge about the largest source of state revenue coming from taxes with an actual total score of 44. Relationship variables tax knowledge and individual taxpayer compliance are 0.792 where the result is included in the interval score between 0.60 - 0.799. It shows a strong both relations tax knowledge and individual taxpayer compliance. Following a theory put forward by experts, tax knowledge is used by taxpayers as tax information in carrying out tax actions, like paying, calculating, and reporting tax paid. Fauziati \& Nasrah (2016) study how essential aspects of tax knowledge for taxpayers significantly affect tax attitudes. Better quality of knowledge will provide a perspective of fulfilling obligations properly through the taxation system considered fair. Then, the most significant percentage value partial determination coefficient of tax knowledge variable towards individual taxpayer compliance is $62.73 \%$.

Meanwhile, the remaining $37.27 \%$ is influenced by many factors that are not examined, such as the quality of tax services, perceptions on the effectiveness of the tax system, tax sanctions, social norms, trust in government, and others. It proves and answers the phenomenon stated previously, namely, the level of taxpayer compliance is still low because there are still many taxpayers who do not fulfill payment obligations (Newman et al., 2018). Results are supported by previous research conducted by Lim et al. (2018), which is shows tax knowledge has a positive and significant effect on taxpayer compliance. It means more insight a taxpayer would be higher taxpayer compliance. 
Effect of Modernization of Tax Administration System on Individual Taxpayers

Results indicate positive and significantly influenced both variables' modernizations of tax administration system with individual taxpayer compliance. The effect of modernization in the tax administration system on individual taxpayer compliance is influenced by several factors. The highest score for modernization of variable is found in effectiveness indicator level through instruments in item 4, namely tax reporting through e-SPT and e-filing is effective, with an actual score of 57 . Relationship both variables modernization of tax administration system with individual taxpayer compliance is 0.909 , which results are included in interval score between 0.80 - 1,000. It shows solid relationships between modernizations of the tax administration system with individual taxpayer compliance. It is the following theory put forward by experts, and taxpayer compliance is influenced by many factors, namely the condition of a country's tax administration systems, services provided to taxpayers, tax law enforcement, tax audits, and applicable tax rates. Besides, a simple tax system is also essential because a more complex tax system will affect taxpayer compliance. Then, a large percentage of the partial determination coefficient value of the tax administration system's modernization on individual taxpayer compliance is $82.63 \%$. Meanwhile, the remaining $17.37 \%$ is influenced by other factors not examined in this study, such as quality of tax services, perceptions of the effectiveness of the tax system, tax sanctions, social norms, trust in government, and others (Bunyamin et al., 2020). Results are supported by previous research conducted by Gashenko et al. (2017) that modernization of tax administration system positively affects taxpayer compliance, whereas, in Biletska's (2020) research, modernization of tax administration system cannot be used as an effort to increase mandatory compliance tax.

\section{Effect of taxpayer awareness on individual taxpayers}

Results indicate a positive and significant influence on taxpayer awareness and individual taxpayer compliance. Several factors influence the impact of taxpayer awareness on individual taxpayer compliance. The highest score for taxpayer awareness variable is found in efficiency indicator through instruments in question number 5, tax paid can be used for state development, with an actual score of 65 . Relationship taxpayer awareness and individual taxpayer compliance are 0.637, included in interval scores between 0.60 and 0.799 . It shows strong relationships between taxpayer awareness and compliance with individual taxpayers. It is the following theory put forward by experts that taxpayer awareness of tax function, as state financing is needed to increase taxpayer compliance (Bunyamin et al., 2020). Attention becomes compliant taxpayer one of compliance with tax law where stated taxation law is indiscriminate and not escape exceptions, both everywhere, and everyone is same based on provisions applicable on tax laws to avoid administrative sanctions will detrimental to taxpayer himself. Then, the score percentage partial determination coefficient of taxpayer awareness of taxpayer compliance amounted to $40.58 \%$. Meanwhile, the remaining $59.42 \%$ is influenced by other factors that are not examined, like the quality of tax authorities, perceptions of the effectiveness of the tax system, tax sanctions, social norms, trust in government, and others. Previous research shows that taxpayer awareness has partially positively and significantly influenced individual taxpayer reporting compliance (Bornman \& Ramutumbu, 2019).

\section{CONCLUSION AND RECOMMENDATION}

Based on the explanation of taxpayer compliance regarding influence variables tax knowledge, modernization of tax administration systems, and taxpayer awareness of Individual taxpayer compliance in Indonesia, we draw the following conclusions taxation knowledge has positively influenced and significantly affected individual taxpayer compliance $62.73 \%$. A positive value explains unidirectional influence. If tax knowledge increases, individual taxpayers' compliance will increase. Modernization of the tax administration system positively influenced and significantly affected individual taxpayer compliance of $82.63 \%$. A positive value explains unidirectional influence. I Individual taxpayers ' compliance will increase if the tax administration system's modernization increases. Taxpayer awareness has a positive and significant effect on individual taxpayer compliance by $40.58 \%$. A positive value explains unidirectional influence. If taxpayer's awareness increases, individual taxpayer's compliance will increase. 


\section{REFERENCES}

An, Y. J., \& Wilson, N. (2016, June). Tax Knowledge Adventure: Ontologies that Analyze Corporate Tax Transactions. In Proceedings of the 17th International Digital Government Research Conference on Digital Government Research (pp. 303-311).

Anggadini, S. D. (2015). Accounting information system quality related to ethics and competence of users. International Journal of Applied Business and Economic Research, 13(5), 3143-3158.

Anggadini, S. D. (2017). Improving the Quality of Accounting Information System Through the Availability of User's Competence. Journal of Engineering and Applied Sciences, 92609265.

Anggadini, S. D., \& Susanto, A. (2017). Study of Resources Allocation on the Implementation of Accounting Information System. Journal of Engineering and Applied Sciences, 92559259. https://doi.org/ 10.36478/jeasci.2017.9255.9259

Azemi, A. B., Palil, M. R., Amir, A. M., \& Said, S. M. (2020). Individual tax fairness in a developing country: perceptions among Malaysian tax professionals. Management \& Accounting Review (MAR), 19(1), 49-72.

Bernard, O. M., Memba, F. S., \& Oluoch, O. (2018). Influence of Tax Knowledge And Awareness On Tax Compliance Among Investors In The Export Processing Zones In Kenya. International Journal of Scientific Research and Management, 6(10).

Biletska, N. (2020). Environmental and Social Commitment Plan (ESCP)-Tax Administration and Statistical System Modernization Project-P163711 (pp. 1-0).

Bornman, M., \& Ramutumbu, P. (2019). A conceptual framework of tax knowledge. Meditari Accountancy Research.

Bunyamin, B., Wiyarni, W., \& Sudaryoto, S. (2020, April). The Impact of Remuneration and Modernization Tax Information System on Employee Performance. In 1st Annual Management, Business and Economic Conference (AMBEC 2019) (pp. 219-227). Atlantis Press.

Cechovsky, N. (2018). The importance of tax knowledge for tax compliance: A study on the tax literacy of vocational business students. Christof Nägele and Barbara $E$. Stalder (Editors), 113.

Evans, C., Carlon, S., \& Holland, K. (2016). Tax knowledge in large corporations: Insights and analysis.

Fauziati, P., Minovia, A. F., Muslim, R. Y., \& Nasrah, R. (2016). The impact of tax knowledge on tax compliance case study in Kota Padang, Indonesia. Journal of Advanced Research in Business and Management Studies, 2(1), 2230.

Gashenko, I. V., Zima, Y. S., Stroiteleva, V. A., \& Shiryaeva, N. M. (2017, July). The mechanism of optimization of the tax administration system with the help of the new information and communication technologies. In International Conference on Humans as an Object of Study by Modern Science (pp. 291297). Springer, Cham.

Kustiawan, M., Prawira, I. F. A., Zulhaim, H., \& Solikin, I. (2019). Tax knowledge, Tax Morale, and Tax Compliance: Taxpayers' View. The International Journal of Business Management and Technology, 3(1).

Li, W. (2017). A Study on the Reform of Procedural Tax System in Chinese Tax Modernization. Journal of Dali University, 05.

Lim, C. Y., Shevlin, T. J., Wang, K., \& Xu, Y. (2018). Tax knowledge diffusion through individual auditor network ties: evidence from China. Available at SSRN 3229564.

Masari, N. M. G., \& Suartana, I. W. (2019). Effect of tax knowledge, service quality, tax examination, and regional compliance tax mandatory technology. International research journal of management, IT and social sciences, 6(5), 175-183.

Mohammed, F., \& Sanusi, S. (2020). Quality of Governance and Tax Revenue Generation In West Africa: A Political Process Theory Perspective. Management \& Accounting Review (MAR), 19(1), 213-232.

Newman, W., Mwandambira, N., Charity, M., \& Ongayi, W. (2018). Literature review on the impact of tax knowledge on tax compliance among small-medium enterprises in a developing country. International Journal of Entrepreneurship, 22(4), 1-15.

Olaoye, C. O., \& Kehinde, B. A. (2017). Impact of information technology on tax administration in Southwest, Nigeria. Global Journal of Management and Business Research. 
Osipov, V. S., Skryl, T. V., Blinova, E. A., Kosov, M. E., Zeldner, A. G., \& Alekseev, A. N. (2017). Institutional analysis of public administration system. International Journal of Applied Business and Economic Research, 15(15), 193-203.

Ouachene, A., \& Belazouz, B. A. (2017). Tax Reforms as a Tool to Modernize and Develop the Tax Administration-with Reference to the Case of Algeria. Revue Académique des Études Sociales et Humaines, (17), 67.

Pratama, A. (2017). Machiavellianism, tax knowledge, and ethical perceptions of tax avoidance: survey of undergraduate students in West Java, Indonesia. International Journal of Trade and Global Markets, 101), 83-90.

Purnamasari, D. I., \& DPS, R. H. (2018). The Effect of Modernization of Indonesia's Tax Administration System on Tax Compliance: A Study of Small Medium Enterprises (SMEs) Taxpayers. International Journal of Computer networks and communications Security, 6(3), 61-65.

Ratnasari, N. P., \& Tjaraka, H. (2020). Individual Taxpayers' Compliance in the Implementation of the Policies on Reduction and Abolition of Tax Administrative Sanction and Active Tax Collection. Talent Development \& Excellence, 12(2).

Solehzoda, A. (2017). Information technologies in the tax administration system of VAT. Journal of Advanced Research in Law and Economics (JARLE), 8(26), 1340-1344.

Veit, A. (2019). Swimming Upstream: Leveraging Data and Analytics for Taxpayer Engagement - an Australian and International Perspective EJournal Tax Res., 16(3), 474-499.

\section{ABOUT THE AUTHORS}

Sri Dewi Anggadini, email: sri.dewi@email.unikom.ac.id

Dr. Sri Dewi Anggadini, SE., M.Si,. Ak. CA is an Associate Professor and Academic at Indonesia Computer University. She teaches Finance and Taxes-related subjects.

Dr. Surtikanti Surtikanti, SE., M.Si., Ak. CA is an Academic at Indonesia Computer University. She teaches Finance and Taxes-related subjects.

Ari Bramasto, SE., M. Si., Ak. CA is an Academic at Langlangbuana University. He teaches Finance and Taxes-related subjects.

Egi Fahrana, S.Kom., BBA, MM is an Academic at Universitas Komputer Indonesia, Bandung, Indonesia. 